\title{
Mobility, multilocality and translocal development: changing livelihoods in the Karakoram
}

\author{
A. Benz \\ Freie Universität Berlin, Centre for Development Studies (ZELF), Malteserstraße 74-100, 12249 Berlin, \\ Germany \\ Correspondence to: A. Benz (a.benz@fu-berlin.de)
}

Received: 26 March 2013 - Revised: 16 September 2013 - Accepted: 4 November 2013 - Published: 11 December 2014

\begin{abstract}
The people of the Karakoram have broadened the basis of their livelihoods over the last two to three generations by diversifying their income sources and activities along sectoral and spatial lines. Formal education, off-farm income generation and professional employment in the cities complement and partly substitute local agricultural activities. Intensifying processes of mobility and migration have created translocal rural-urban livelihoods, straddling between various and often geographically distant places. Social ties in multilocal configurations of households, families and communities have established highly effective local-to-local connections, which directly interlink processes of change and development in different locations. This article traces in a historical analysis the specific interrelations of mobility dynamics, livelihood change and socio-economic development for the Wakhi community of Gojal in northern Pakistan and discusses the potential of translocal livelihoods to overcome local constraints and facilitate development in structurally disadvantaged regions.
\end{abstract}

\section{Introduction}

The Pakistan-administered north-western Karakoram region shows very high rates of intra- and extra-montane mobility and migration ${ }^{1}$, leading to significant shares of absent people within households, family networks and village communities. These regional characteristics line up with the general dynamics of rising mobility and increasing out-migration which have been described for many South Asian mountain areas (Bose, 2000; Hoermann and Kollmair, 2009; Sati and Singh, 2009). Continuous population growth, scarcity of arable land, limited opportunities for marketing agricultural produce and insufficient off-farm employment and income opportunities characterise the restrictive conditions in the north-western Karakorum for making a living based on local resources. Particularly young men and women often

\footnotetext{
${ }^{1}$ The concept of spatial mobility comprises all forms of movement of people in space, irrespective of distance, duration and frequency (Bähr et al., 1992:539-540). In this article, migration is defined as all those acts of spatial mobility of people, which imply a shift of residence for at least three months (cf. Bähr et al., 1992:541; Faist, 2000:19).
}

see little future in the high-mountain villages for them and their children and move to the urban centres in search of education, employment, income and a more comfortable life. The population drain of the young and most educated has often been identified as a threat to development in mountain regions (Hegland, 2010; Hoermann and Kollmair, 2009; Olimova and Olimov, 2009). The case of the Gojal region in northern Pakistan strongly questions these assumptions and presents a different picture. In spite of of high out-migration rates, Gojal has turned within only a few decades from an underdeveloped mountain periphery suffering from frequent famines, high mortality rates and pervasive illiteracy into one of the leading regions of rural Pakistan in terms of human development.

The Gojalis have broadened the basis of their livelihoods by diversifying their income and activities along sectoral and spatial lines. Beyond their continued engagement in combined mountain agriculture for the purpose of self-use and limited cash-crop marketing, they are engaged in a broad range of off-farm income generating activities, utilising resources and opportunities at various and often distant locations. Part and parcel of these diversification strategies are 
increasing levels of mobility. Migration to urban centres, formal education and professional employment have become key pillars of livelihoods. In the course of continued migration processes, households, family networks and whole communities of Gojal gradually took a multilocal shape ${ }^{2}$, straddling between rural and urban settings. Flows of remittances, goods, information, ideas, imaginaries and people have closely interlinked developments, resources and opportunities in the different spatial anchoring points of their translocal livelihoods. The sum of these networked, interdependent processes of change, which link the local to the local elsewhere go beyond established notions of "regional development" and rather have to be interpreted as patterns of translocal development and change (Zoomers and van Westen, 2011). By tapping external resources through migration and translocal strategies, the Gojalis could strongly broaden the spectrum of viable livelihood options.

This paper aims at gaining a deeper understanding of the specific interrelations of mobility dynamics, livelihood change and socio-economic development with the help of the case of Gojal. By analysing how people from a structurally disadvantaged region successfully managed to overcome local constraints and to trigger a lasting process of development in their community through the pursuance of translocal livelihood strategies, this paper also contributes to ongoing debates on the migration-development nexus.

For this purpose, I will reflect in the following section on the analytical potentials and constraints of livelihoods frameworks applied in multilocal contexts and discuss conceptual enhancements based on the idea of translocal development. Subsequently, the particular historical trajectory of mobility expansion, livelihood change and socio-economic development is outlined for the case of the Gojali Wakhi, followed by a detailed analysis of current translocal livelihoods and their outcomes in the light of the concept of translocal development. In the concluding section, implications of the empirical findings for the conceptualisation of development in contexts of mobility and translocality are drawn and the potentials of translocal livelihoods for development discussed.

\section{Stepping beyond the livelihoods framework: new mobilities, multilocality and translocal development}

For more than two decades, livelihood approaches (Carney, 1998; Chambers, 1987; Chambers and Conway, 1992; DFID, 1999; Scoones, 1998), have been among the preferred tools and frameworks to analyse people's strategies in rural as

\footnotetext{
${ }^{2}$ Multilocality in this paper is understood as a notion describing the spatial configuration of a set of elements (e.g. family members) which are dispersed across two or more geographical locations. Translocality here is understood as describing the interactions as well as functional and imagined relations between elements in multilocal networks.
}

well as urban contexts to make a living under conditions of risks and resource scarcity in dynamically changing contexts. As a micro-analytical and actor-oriented tool, it focusses on the micro-cosmos of households, their access to and endowment with different types of resources (livelihood assets), and their decisions on resource utilisation (livelihood strategies) to make a living (livelihood outcomes) in certain contexts (vulnerability context, transforming structures and processes). The strength of the approach lies in providing a better understanding of the subjective logic of decisionmaking and the actions taken by household members. Despite of having received a wide range of criticism, which pointed out its theoretical and heuristic limitations, the approach is still considered by many as an indispensable tool for gaining a better understanding of rural (de Haan, 2012; de Haas, 2010; King, 2011; Mazibuko, 2012; Scoones, 2009; Steinbrink, 2012) as well as urban (Farrington et al., 2002; Lohnert and Steinbrink, 2005; Rakodi, 1995, 2002) dynamics at the micro level. It is widely agreed on that the livelihood approach's weakness in conceptualizing (macro-) structural factors (Müller-Mahn and Verne, 2010; Scoones, 2009) and societal power relations beyond the realm of the household (de Haan, 2008, 2012) necessitates its complementation with other theoretical and analytical approaches (Bebbington and Batterbury, 2001; de Haan, 2012; Thieme, 2008; van Dijk, 2011).

Other weaknesses of the approach have been tried to overcome by refining and advancing the framework from within, e.g. by overcoming its blind spot for the spatial dimension of livelihoods (King, 2011). "Classical" livelihood approaches largely failed to grasp spatial mobility and migration dynamics in rural households, family systems and communities. While paying much attention to sectoral diversification (Ellis, 1998, 2000), the approach was largely unable to grasp the spatial diversification of livelihoods and income sources (King, 2011; Steinbrink, 2012). It was widely ignorant to the emergence of multilocal configurations of households, having its members spread across a number of geographically distant places. Due to these drawbacks, livelihood studies had difficulties in dealing with the new mobilities in the rural periphery of the Global South. Attempts to broaden the scope of livelihood approaches by taking into account the increasingly multilocal network character of social units and their livelihood activities, have been made in concepts such as "multilocal livelihoods" (de Haan, 2008; de Haan and Zoomers, 2003; Elmhirst, 2012; Thieme, 2008), "translocal livelihoods" (Greiner, 2010, 2012; Lohnert and Steinbrink, 2005; Long, 2008; Steinbrink, 2007, 2012) and "transnational livelihoods" (Bebbington and Batterbury, 2001). The common ground of these new concepts is a translocal and relational perspective on livelihoods as coordinated activities in social networks spreading far beyond the local sphere, and by this overcoming the "territorial trap" of classical livelihood approaches (Geiger and Steinbrink, 2012). Scholars of livelihood studies turning their attention to spatial mobility and its 
outcomes, and scholars from migration studies increasingly acknowledging the importance of livelihood contexts, met in the middle and discovered a joint field of scholarly interest. Based on the insight that "the impact of a migration strategy cannot be evaluated outside its relationship with other livelihood strategies, that is, the entire portfolio of multilocal and multisectoral household activities" (de Haas, 2007a:54), they stress the necessity to consider migration in the context of translocal livelihoods and vice versa. Migration studies and development studies have to some extent converged around the idea of livelihoods being sustained in translocal social networks, based on spatial mobility (Geiger and Steinbrink, 2012). Consequently, the need for a contextualised, relational and translocal perspective is strongly emphasised in the ongoing debates on the migration-development nexus (de Haas, 2010, 2012; Skeldon, 2010).

In light of this new perspective, Zoomers and van Westen (2011) argue for the need of a refined notion of "local" development. Building on Massey's (1991) relational concept of space, in which "any locality [is conceptualised] as a specific node in which numerous networks of different nature meet" (Zoomers and van Westen, 2011:378), they suggest the concept of "translocal development". The central idea is to free the notion of development from its strong territorial focus (as expressed in terms like "local", "rural" or "regional" development) and instead establish a relational conception of interlinked processes of social change in different locations, stressing on aspects of spatial interconnectedness and the importance of local-to-local connections (Zoomers and van Westen, 2011:378). Established regionalisations and categories of spatial dichotomy (e.g. rural-urban) are increasingly blurred by translocal livelihoods and social networks straddling between rural and urban places (Greiner, 2010; Steinbrink, 2007, 2009; Steinbrink and Lohnert, 2012). This does not mean to discard the idea of "local" development. To the contrary, it is broadened by placing "local" development in a pluralistic web of interdependent "local" developments in other places. Taking translocal links and spatial connectivity into account "generates additional perspectives for 'local' development" by drawing attention to the complex "interplay between local and extra-local influences" in a particular place (Zoomers and van Westen, 2011:380).

In the course of ongoing translocalisation of social networks and social units certain solidified links of "more than occasional nature" (Zoomers and van Westen, 2011:380) evolve between particular places, whose "local" developments and changes become closely interlinked through flows of money, goods, information, ideas and people. Migration processes play a crucial role in the emergence of such "development corridors" (Zoomers and van Westen, 2011:380): "A connection between two localities might be initiated by somebody's decision to migrate from A to B. This initial move may subsequently trigger a whole set of new relations, the blurring of types of interactions and/or the development of new mobilities including linking new localities to this growing corridor" (Zoomers and van Westen, 2011:380). By this, whole networks of interconnected places evolve, whose particular temporal-spatial trajectories can be traced in a historical analysis.

The analysis of the particular translocal development trajectory of the Wakhi of Gojal undertaken in the remainder of this paper is based on results of a total of three months of field research conducted in 2011 and 2012 in the region. Key sources are migration histories of people from the villages of Hussaini and Passu, which have been collected in householdbased village surveys ${ }^{3}$, as well as biographical, oral history and focussed narrative interviews conducted with former and current migrants ${ }^{4}$, village elders, teachers and representatives of village organisations and social sector NGOs. Following a multi-sited approach (Marcus, 1995), interviews have been conducted in different locations of the migration network ${ }^{5}$. The historical trajectory of mobility and livelihood change in Gojal has been reconstructed from these sources and contextualised with general dynamics of framework conditions.

\section{Trajectories of livelihood change and mobility dynamics among the Wakhi of Gojal}

The Wakhi of Gojal are an ethno-linguistic group of Ismaili Muslims speaking the Wakhi language, an eastern-Iranian vernacular. They currently constitute about two thirds of the approximately 20000 inhabitants of the Gojal Tehsil (Sökefeld, 2012:177), an administrative sub-unit of the HunzaNagar District in Gilgit-Baltistan, northern Pakistan (Fig. 1). The Wakhi of Gojal originate from the Wakhan Valley in today's Afghanistan and Tajikistan, and migrated in subsequent waves from about the late 18th century onwards into the Gojal region. Their permanent settlement as farmers was favoured by the mir (the local feudal ruler) of Hunza as part of his strategy of territorial expansion (Kreutzmann, 1989:46-47). The new immigrants were heavily taxed and subject to compulsory labour in the feudal Hunza state. Their livelihoods fully depended on combined mountain agricul-

\footnotetext{
${ }^{3}$ A standardised survey has been conducted with one adult representative of every household, in most cases with the household head, in Hussaini and Passu (full coverage) with the help of local field assistants in the local Wakhi language and documented in questionnaires in English. The survey reveals, among others, the migration biographies of all present and absent household members as well as close relatives of the household head. In total 1750 individual migration biographies have been documented.

${ }^{4}$ To deepen and contextualise the survey data, selected guided narrative and biographical interviews have been conducted with 45 former and 33 current migrants either in English or in Wakhi with the help on an interpreter. Interviews have been recorded and transcribed for documentation and analysis.

${ }^{5}$ Fieldwork has been conducted in the Gojali villages of Hussaini, Passu and Gulmit, in different villages of Central Hunza, in the regional centre Gilgit and in the capital city Islamabad.
} 


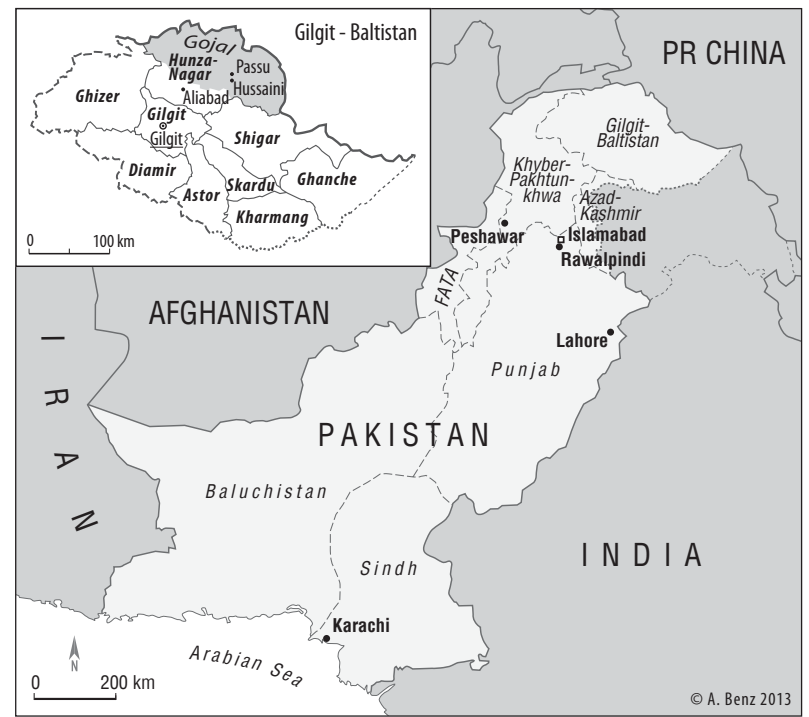

Figure 1. Map of Pakistan and Gilgit-Baltistan.

ture run on a scarce local resource basis and were vulnerable to natural hazards, entailing frequent periods of famine and allowing only for a life in a severe state of poverty (Malik and Piracha, 2006). Spatial mobility was highly restricted by the Hunza state, and leaving its territory required a special permission, issued by the mir and accompanied by high fees (Kreutzmann, 1989:162, 1996:289; Sökefeld, 1997:87). This permission system meant a nearly complete prevention of outward mobility for the vast majority of the population. It was only in the early 1940s that the travel restrictions gradually ceased to be in effect. After the establishment of Pakistan in 1947, the grip of the mir on controlling mobility further dwindled, allowing people to seek new livelihood opportunities beyond the boundaries of Hunza.

In the late 1930s and early 1940s, service in the military forces provided the first off-farm monetary income opportunities for common men from Gojal. The British, who had conquered the Hunza state in 1891 and had established a system of indirect rule under a newly-installed loyal mir, had set up a local military regiment in Gilgit. Local enlistment provided income opportunities for young men from the region, including from Hunza since 1913, but the mir of Hunza banned Wakhi men from military service at least until 1935 (Kreutzmann, 1996:288). The recruitment of the first Wakhi from Gojal in the Gilgit Scouts and in the British colonial army in the late 1930s marks a turning point and the beginning of a lasting process of spatial and sectoral livelihood diversification and increasing migration of the Wakhi. The early mercenaries from Gojal were the first commoners to earn regular cash income. They experienced urban life, learned about job and income opportunities in the cities and were impressed by the large number of children attending schools. In Gojal, the first boys' primary schools were estab-

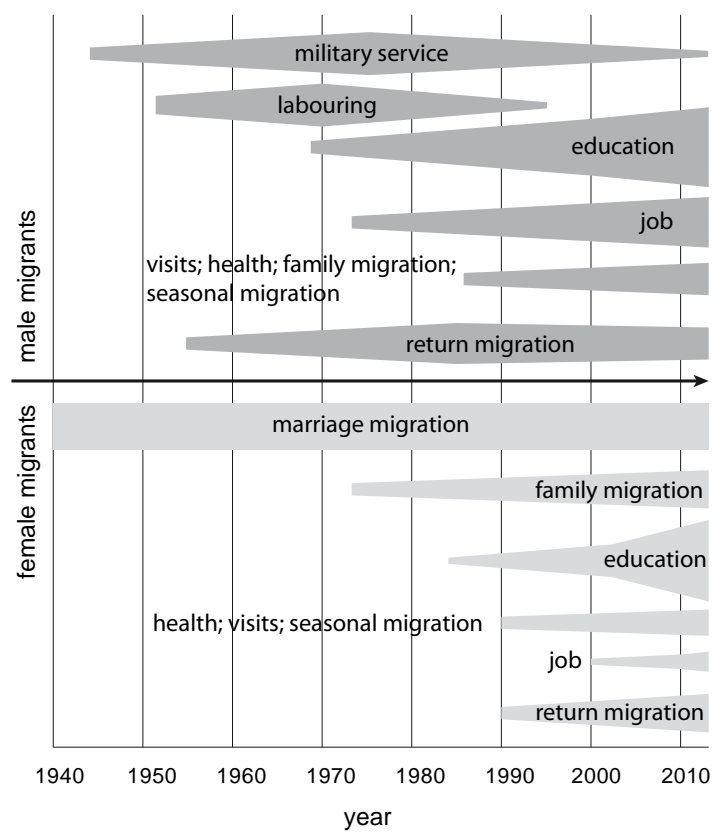

Main migration types and their changing importance over time, exemplified for the village of Hussaini based on the analysis of 891 acts of migration. Data: Benz, Hussaini Village Survey 2012. Design: Benz 2013.

Figure 2. Changing patterns of migration from the village of Hussaini.

lished in 1946/47 on initiative of Sultan Muhammad Shah, Aga Khan III, the then spiritual leader of the Ismailis. Before that, formal education was the exclusive privilege of the feudal elite and inaccessible for the common people (Nazar, 2009).

With their pay from the military and their knowledge about opportunities in the cities, the early military migrants provided important preconditions for the subsequent stage of mobility change: the onset of unskilled male labour migration from Gojal into the cities in the early 1950s (Fig. 2). As could be seen from many early migrants' biographies, it was close male family members of the early mercenaries who, with their financial support and personal assistance, first overcame the challenge to leave their village and to find labouring positions in the city (Benz, 2013a). Nearly all of these early labour migrants went to Karachi, which has remained a prime destination for Gojali migrants until the present (Fig. 3). At first sight, this choice of destination may seem unexpected, since these early migrants could not build on pre-established personal ties, social networks and exchange relations to Karachi, and, for migrants from Gojal, Karachi marks the geographically most distant place among the many urban centres within Pakistan. The explanation of the specific "Karachi-factor" requires a twofold answer. First, Karachi as the primary industrial and economic centre of the country, was a boom-town in the 1950s, and provided abundant job opportunities at very low costs 
of living. Young people from rural areas all over Pakistan were attracted to Karachi as "the mother of the poor", as it is still termed by many early migrants. Second, Karachi is home to the khoja Ismailis, an affluent trader and business community, who recognised in the migrants from Gojal and Hunza their poorer Ismaili brothers from the mountains, which they called maulai (Kreutzmann, 1996:45). Based on symbolic ties of being Ismaili, a small religious minority in Pakistan, many khoja supported the maulai migrants and provided them with jobs in their factories, hotels and enterprises, as well as by employing them as domestic servants in their homes. The migrants from the north and their fellow Ismailis of the khoja community came together on many occasions in the jamat khana (community centre and prayer hall). These frequent meetings not only deepened the relations between maulai migrations from different villages, but also brought them into close contact with the khoja and opened channels for solidarity and assistance. Backed by this support, the maulai could establish themselves in Karachi as a well-organised diaspora. ${ }^{6}$ The early labour migrants started to serve as brokers for subsequent migration from their home communities. Male relatives and co-villagers were encouraged to follow them to Karachi and were procured with jobs and dwelling places. Saving groups and small-scale loans were organised among the maulai diaspora in Karachi to enable the migrants' occasional visits to their home villages.

The migration network from Gojal started to expand and grew in numbers as chain migration gradually gained momentum. A migration corridor to Karachi began to emerge, which gradually turned into a development corridor, when the migrants' remittances reached their home villages in form of cash, household goods, clothes and food. Even more importantly and with a sustained impact, the early labour migrants enabled other male family members to acquire higher education in Karachi. This early shift from unskilled labour migration to education migration was a decisive step. It set the course for an "educational revolution" and subsequent socio-economic developments which characterise the specific translocal development trajectory of the maulai, and which distinguishes them from many other mountain communities. The maulai migrants in Karachi were confronted with the pronounced esteem for education among the highly cultured khoja Ismailis and took them as a role model. Additionally they were inspired by numerous religious messages and teachings of the Aga Khan III and his successor Shah Karim, Aga Khan IV, who made education efforts obligatory for all their followers. Guided by these experiences, many Gojali labour migrants took their brothers, cousins, nephews or sons with them to Karachi for their further ed-

\footnotetext{
${ }^{6}$ Parts of this diaspora became politically organised and agitated for the abolition of feudal rule in Hunza. They won the support of then Pakistani Prime Minister Zulfikar Ali Bhutto and his Pakistan Peoples Party (PPP), which eventually led to the disempowerment of the mir of Hunza in 1974.
}

ucation. Some of the labour migrants themselves got enrolled in night schools and colleges and continued their education in Karachi. Most of the early student migrants had to work part-time besides their studies. Often they worked at night and studied in daytime, or vice versa, and were thus able to largely self-finance their studies. In most cases, they could not expect any financial support from their parents, who did not command any monetary income. In the 1960s, livelihoods in Gojal were still characterised by subsistenceoriented combined mountain agriculture and by largely lacking local off-farm income opportunities. Important support for maulai students in Karachi came from some khoja Ismailis, who learned about the hardships of their fellow Ismailis and provided informal scholarships for needy students. In this migration phase, it was less the labour migrants' marginal remittances which effected development, but rather their offer of on-site support to family members following them to Karachi, thus providing them with access to new livelihood opportunities.

Many early student migrants from Gojal managed to continue their education beyond the higher secondary school level, which meant an impressive leap from mostly illiterate family backgrounds. The 1970s saw the first college and university graduates emerging from the Gojali student migrants, who subsequently found employment in well-paid professional positions in different Pakistani cities. They not only established new anchor points of the expanding Gojali migration network in Lahore, Peshawar, Islamabad and Rawalpindi, but also were able to better support the next generation of student migrants thanks to their decent income. Due to well-established family solidarity and resource redistribution systems among the Wakhi of Gojal, many family members benefitted from an individual person's good position and high income. Expectations of solidarity and reciprocity prevent individual use of resources, but rather encourage supporting relatives with money, accommodation and food, contacts and facilitation in situ as well as across the different locations of evolving translocal family networks. Remittances were increasingly transferred between "third places" of these family networks without reaching the Gojal region. The success and income of the first professionals enabled a sharp rise in the numbers of still predominantly male student migrants from Gojal, again mainly heading to Karachi. At the same time, unskilled labour migration lost its former importance (Fig. 2).

Female education started to spread in Gojal in the late 1960s with the establishment of the first girls' primary schools. The female educational expansion, setting out from literacy rates below one percent, unfolded in an unprecedented pace and turned Gojal into one of the leading regions of female education within Pakistan over the course of only about three decades (Benz, 2012, 2013b). In the early 1980s, the first young women continued their education outside Gojal, marking the beginning of female student migration, which strongly gained momentum in the 

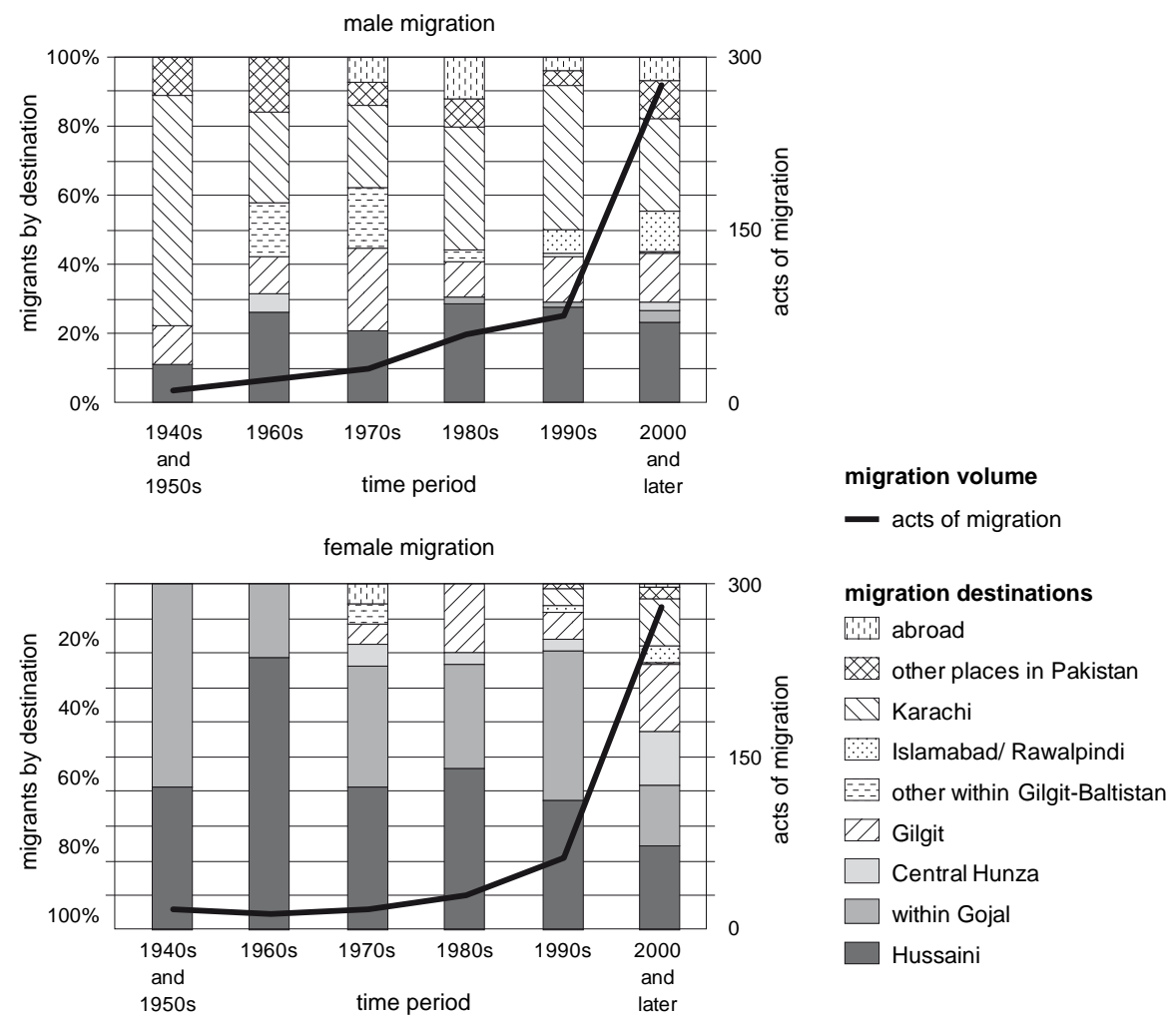

Acts of migration ( $n=891$; seasonal migration excluded) of Hussaini households' members, separated sons and daughters, and brothers and sisters of the household heads ( $\mathrm{i}=809)$. Data: Benz, Hussaini Village Survey 2012. Design: Benz 2013.

Figure 3. Rising levels and changing destinations of migration from Hussaini.

subsequent years. Prior to that, out-migration from Gojal was an exclusively male domain due to socio-cultural constraints preventing women from travelling, living and working on their own. Female student migration became only possible within translocal family networks, which provided opportunities for co-habitation, protection and company by male kin in places outside Gojal and the necessary financial resources to afford hostel accommodation.

Since the 1950s, the road network was gradually expanded and improved in the region, turning former mule tracks into roads which for the first time allowed motorised traffic into the Hunza Valley. Particularly the opening of the Karakoram Highway in 1978, which is connecting "down-country" Pakistan via the Indus and Hunza Valleys to China, and which is directly linked to the major villages of Gojal, tremendously improved accessibility of the region. Travel time and travel costs to the cities in the Pakistani lowlands shrunk, providing new opportunities for cash-crop marketing and making available a huge variety of consumer goods in local bazaars. Food supply of local households increasingly depended on purchased items since the local production base was less and less capable to sustain the growing population. This made monetary income a necessity for virtually all households. At the same time, the income opportunities multiplied since the late 1970s. In the early 1980s, when the region was opened for foreigners, international tourism became a growing business in Gojal. The new road connection provided opportunities for petty trade across the Chinese border and made Gojal attractive for the production of niche cash-crop products, mainly potatoes and different varieties of fruit. Cash-crop production and marketing were facilitated since the 1980s in projects conducted by the Pakistani government, international donors and the Aga Khan Rural Support Programme (AKRSP). Despite these efforts, the agricultural sector in most households did no longer suffice to make a living and soon stood secondary to the off-farm sector activities, whose importance had rapidly grown.

The expanding public administration and government services as well as development programmes of different NGOs provided new local off-farm income options, in which returning student migrants found qualified professional employment. Particularly the projects of the Aga Khan Development Network (AKDN) provided the first professional employment opportunities for women, in which many of the first female graduates from Gojal have found jobs since the 1990s. Thanks to their education and their new role as "bread winner" for their families, gender roles changed in a process 


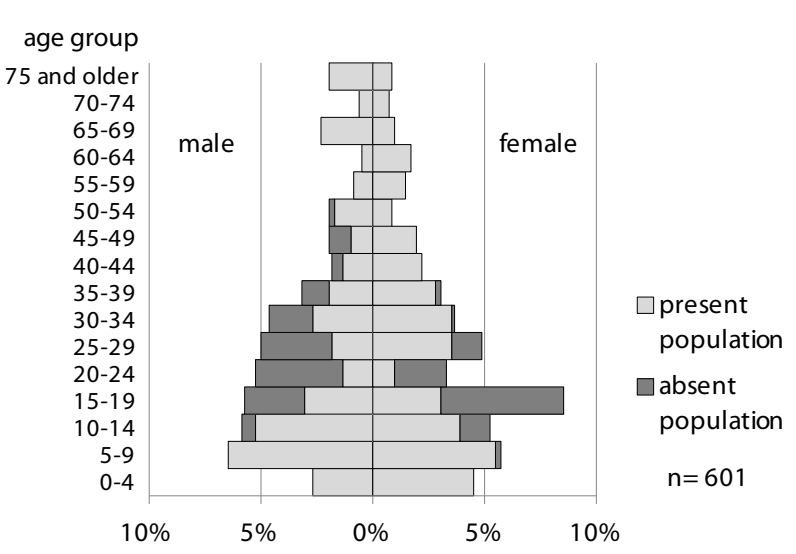

Data: Benz, Hussaini Village Survey 2012. Design: Benz 2013.

Figure 4. Age structure and residence status of the population of Hussaini.

of women's empowerment, resulting in a much improved status of women in society.

While the large majority of the early military and labour migrants returned to their home region and re-engaged in agriculture or established small-scale enterprises (Benz, 2013a), many Gojali student migrants did not return after completion of their studies and rather settled in various Pakistani cities where they found professional employment. Since the 1980s, international migration started to play a role in form of male labour migration to the Arabic Gulf states and male student and professional migration to Western countries such as Canada, USA, Australia or UK. Female international migration from Gojal at this time has not yet stepped beyond few individual cases of women leaving for post-graduate studies or professional trainings mostly in Western countries. A number of international marriages of men from Gojal to mostly Western and Japanese women who had visited as tourists to the region, further broadened the scope of the translocal Wakhi networks up to the global level.

In a process of migration-driven translocalisation, the Gojali Wakhi have turned from a community confined and spatially fixed within the borders of the feudal Hunza state and suffering from local development constraints and scarcity of resources, into a highly mobile, translocally organised and globally linked community. They strongly benefitted from translocal strategies tapping external resources and accessing new opportunities, resulting in high levels of education, professional employment and increasing income. A deeper understanding of these translocal strategies and their socioeconomic outcomes will be provided in the following section by taking a closer look into current livelihoods systems.
Table 1. Spatial distribution of Hussaini's population.

\begin{tabular}{lll}
\hline $\begin{array}{l}\text { Current place of residence of } \\
\text { Hussaini household members }\end{array}$ & Male & Female \\
\hline Hussaini & 211 & 233 \\
Other places within Gojal & 8 & 18 \\
Central Hunza & 4 & 16 \\
Gilgit & 27 & 23 \\
Other places within Gilgit-Baltistan & 1 & 1 \\
Islamabad/Rawalpindi & 15 & 0 \\
Karachi & 16 & 3 \\
Other places in Pakistan & 12 & 3 \\
Saudi Arabia, UAE, Bahrain & 5 & 0 \\
Other foreign countries & 4 & 1 \\
\hline Total & 303 & 298 \\
\hline
\end{tabular}

Data: Benz, Hussaini Village Survey 2012.

\section{Recent trends and patterns of diversified translocal livelihoods}

Current livelihoods of Gojali households rest on a range of spatially and sectorally diversified activities and income sources, of which a substantial part is realised in the context of migration and coordinated in multilocal household and family structures, as can be seen, for example, in the village of Hussaini.

At the time of fieldwork in October 2012, about a quarter of Hussaini's population ${ }^{7}$ were absent migrants. Particularly the young and economically active had migrated, with shares of over $60 \%$ absentees in the age group of 15 to 24 years (Fig. 4). The choice of migration targets is highly genderspecific (Table 1). While female migrants predominantly move to places within Gojal, Central Hunza and Gilgit, male migrants mostly opt for Gilgit, "down-country" cities and for foreign countries. The majority of male migrants are engaged in income-generating activities and are sending remittances, while most female migrants are pursuing education.

Most Hussaini households are organised in multilocal configurations. $76 \%$ of the households show at least bi-local settings (i.e. having a member in at least one place outside Hussaini), and $42 \%$ show multilocal settings, having their members spread across up to six different places. The biographies of many current residents of Hussaini (62\% of the men and $20 \%$ of the women) bear migration episodes outside

\footnotetext{
${ }^{7}$ The village population here is defined as all people who are part of a Hussaini-based household plus all people who reside in the village. I consider a person absent, when he or she is living since at least three months outside the village. A household here is defined as consisting of the head of household, his or her spouse, all people living in their family home, all unmarried children of the household head and all married sons and married brothers of the household head with their wives and children, who themselves or their wives live in the household head's family home.
} 
Hunza, which indicate former periods of multilocality of their households. Return migration always played an important role. Among the 30 to 65 year-olds, about every second migrant had at least temporarily returned to Hussaini at the time of fieldwork. Return is often followed by a new round of migration or successive back-and-forth movements entailing circular patterns of migration and stressing the fluidity of multilocal configurations. Opportunities for migration are broadly spread across households of different socioeconomic backgrounds, as indicated by a share of over $90 \%$ currently or formerly practicing migration strategies. Nevertheless, eight out of 84 households of Hussaini did not participate in migration strategies so far. They are characterised by comparatively low adult education levels, low monetary household income, lack of members in formal employment, and high dependency on agriculture and occasional labouring. In addition, they have only very few or even no other migrants among their close relatives, thus largely lacking translocal links and opportunities for on-site support at possible migration targets.

Education is in high esteem among the people of Gojal, and even in the poorer households virtually all sons and daughters are sent to school. Students aspiring higher levels of education are forced to leave their home region due to lack of local institutions. More than $90 \%$ of the young generation of Hussaini, both male and female, continue their local middle or high-school education in other places, often up to the university level. The choice of study location differs considerably for the genders. Male students at the higher levels of education study in Gilgit (36\%), Karachi (28\%), Islamabad/Rawalpindi (10\%) and other cities in Pakistan. Female students in contrast mostly study in Central Hunza (29\%) and Gilgit (41\%). Both places not only bear the advantage of a short travel distance from home, but also provide the social environment of a local Ismaili community and, as often stressed by local interview partners, the availability of hostel facilities and educational institutions perceived as "safe" and "trustworthy", where parents know their adolescent daughters to be in "good hands". The choices about migration targets are usually taken in joint household decisions, with a major say of the head of the household and/or the parents of the leaving migrant, but usually respecting the migrant's own preferences. For female migrants, these decisions are also guided by social norms which prevent young women from living alone or in shared rented flats with friends. For them living in a family context or in a reliable student hostel environment and having male relatives at the migration target are generally considered obligatory and limit the range of possible study sites. Also many male students study at places where they have relatives, who support them by making them a temporary family member, bearing the students' living expenses and sometimes even cover their education fees. In addition, many migrant students benefit from remittances sent by family members from other places. Access to higher education for Gojalis largely depends on resources and opportu- nities provided in translocal household and family networks. The same is true for access to other basic services. Due to insufficient medical facilities in Gojal, access to specialised health care still largely depends on mobility to central Hunza, Gilgit or Karachi.

Even though more and more women are entering professional employment, monetary income generation is still predominantly a male affair. Among the 18 to 60 year-olds, $50 \%$ of the men, but only $12 \%$ of the women were engaged in remunerated activities. Nearly $90 \%$ of all labour migrants from Hussaini are men. Many highly-educated women after marriage assume the role as housewives and mothers and stay without formal employment.

The spatial and sectoral allocation of the workforce reflects the unequal returns on activities in different fields. About half of Hussaini's male workforce (aged 18 to 60 years) is absent from the village and either working or studying. Only a minority of the non-migrated workforce is still primarily engaged in agriculture. For households it is much more rewarding to employ particularly their most educated and skilled male members in non-local and offfarm occupations, which reap higher benefits and income. Translocal strategies pay off much more for most households than activities based on local resources. The importance of agriculture in the household economies has decreased in favour of the rising off-farm sector. In the former Gilgit District, of which Gojal was part of, the share of farm-income has shrunken from $54 \%$ in the mid-1990s to $37 \%$ in 2005 (AKRSP, 2007:16). In Hussaini the respective share was only $22 \%$ in 2009. Livelihoods now chiefly depend on non-farm income, of which the bigger part is generated by labour migrants outside the region and reallocated through remittance flows.

The migrated workforce of Hussaini is engaged in a broad range of non-agrarian activities in different cities, particularly in Gilgit, Islamabad/Rawalpindi and Karachi. They are mostly working in skilled professions in different fields. Some are running their own business as traders or tour operators, and only a minority is engaged in unskilled occupations. Substantial remittances are sent by international labour migrants from the Arabic Gulf states, where currently six men from Hussaini are working, and from three men from Hussaini working in Malaysia.

In addition to numerous back-and-forth movements and circular migration performed in the context of translocal livelihood strategies, a considerable rate of "permanent" outmigration of whole households can be seen. Since the 1960s, at least 16 such shifts occurred from Hussaini, half of them directed to Karachi. Most of the "permanent" out-migrants keep up close ties to their region of origin and regularly visit with their families for summer vacations or to take part in life-cycle ceremonies. They firmly remain part of translocal family networks. Often relatives from the region temporarily join them to their new urban home for family visits, education, health treatment, professional employment or holidays. 
Even decades after their out-migration, many of the resettled Gojalis still consider their village and the Gojal region as their home and a central element of their identity. The feeling of a shared identity among many migrants from Gojal is constructed around an imagined and idealised home region Gojal, which is re-enacted and displayed in cultural festivities with "traditional" costumes, music, dance and recitations of poems at the different locations of the diaspora. Another kind of tie refers to Gojal as a region of last refuge in times of political and economic crisis and sectarian violence. Many migrants retain ownership of land and houses in their village so that they have the option of return at anytime.

With more and more households having ties outside the region, seasonal migration from Hussaini to the cities, mostly during the harsh winter months, has gained momentum. Especially old people move to their out-migrated sons to Gilgit, Rawalpindi or Karachi and stay with them for a few months before they return to the village in spring. Some households from Gojal have established a second home (often in Gilgit) or even a third home (often in Rawalpindi/Islamabad or Karachi), with their members circulating between the different family homes, blurring any clear allocation of a person to a particular place of residence.

Translocal ties within households, family networks and the broader community have led to increased levels of resilience, i.e. the capacity to cope with shocks and to manage and overcome crises. This was demonstrated by the strong coping capacities which were mobilised through translocal networks in form of remittances and the provision of alternative opportunities when the important tourism sector in Gojal suffered from a complete breakdown after the terror attacks of 11 September 2001 in the USA. It again showed in the aftermath of the Attabad rockslide of 4 January 2010, which permanently blocked the Karakoram Highway, the lifeline of the region, and submerged large proportions of village land by a newly formed lake behind the barrier (Sökefeld, 2012). Livelihoods were hit hard by the consequences - a nearly complete halt of local income from cash-crop production, tourism and cross-border trade, accompanied by rising commodity prices in local markets. Thanks to the translocal networks of Gojali households, income losses could be mitigated by translocal support flows.

\section{Conclusions}

The preceding analyses of the historical trajectory of livelihood change and of the current translocal livelihood systems of the Gojali Wakhi have revealed the specific interplay of mobility, livelihood dynamics and socio-economic development for this case. In the context of steadily rising rates of out-migration and circulation since the 1940s, households and family systems have turned into multilocal structures. Countless new local-to-local links were established with major implications for socio-economic development in the com- munities of Gojal. Migration and translocal strategies have considerably broadened the spectrum of viable livelihood options by providing access to resources and opportunities at distant places, thus overcoming local constraints. Only by this, access to higher education, better health treatment and qualified jobs could be provided for many Gojalis, resulting in enhanced human capabilities and rising income levels. In terms of formal education, the people of Gojal have managed to turn a region showing literacy rates of less than one percent and lacking any formal educational institutions before the late 1940s, into one of the leading regions of rural Pakistan. With $100 \%$ school attendance and youth literacy rates for boys and girls, and more than $30 \%$ of the young generation holding bachelor's or master's degrees, the region even competes with the leading urban centres of the country.

Gojal provides a success story which seems to fit well into the new wave of migration optimism currently dominating the debates on the migration-development nexus. Can migration and translocality provide the long-sought-after key to development for structurally disadvantaged regions? In light of recent empirical evidence, de Haas warns against "overly optimistic views that somehow portray migration as a silver bullet development "fix"' (de Haas, 2012:10) and stresses the importance of structural contexts for development impacts of migration. "Structure matters" (de Haas, 2010a:258) in the case of Gojal, too. To put the Gojali example into a broader context requires accounting for the specific conditions which were central for the success of its development path. The political integration of Gojal into the state of Pakistan entailed large-scale road infrastructure projects, most importantly the construction of the Karakoram Highway, which eased travels, provided access to new markets and increased the accessibility of the region. Formerly confining travel restrictions were removed with the end of feudal rule. Development initiatives by the state and non-governmental organisations, particularly the Aga Khan Development Network, provided basic education and new sources of monetary income, which both facilitated migration. In the case of Gojal, comparatively low socio-economic disparities at the onset of migration and the participation of people from all social classes in migration strategies, secured a broad distribution of benefits. A distinct group identity, a strong corporate feeling and a pronounced sense of community among the Wakhi of Gojal provided valuable social capital and the basis for intra-communal support, which was crucial especially in the pioneering years of migration. Well-established community-based institutions provided additional support for migrants, e.g. in form of micro-credits. Strong family values and the active awareness of even remote kinship relations shape every-day interactions and form a reliable basis for family resource redistribution and solidarity systems. Support from the wealthy and influential group of the khoja could be won by pioneering Gojali migrants to Karachi based on a shared Ismaili identity. The guiding messages of the Aga Khan, encouraging his followers to adopt an entrepreneurial 
attitude, to strive hard to acquire higher education and to enter professional careers, certainly had a major impact in shaping the aspirations of the Gojalis. The specific combination of the outlined political, economic, infrastructural and socio-cultural factors provided the structural context which allowed for the particular migration and development trajectory of Gojal.

Insights from the Gojali example point to blind spots and shortcomings in the ongoing debates on the migrationdevelopment nexus and suggest revisiting some of its central concepts. A strong focus on remittances and renewed hopes in contributions of return migrants characterise recent discussions (de Haas, 2010:230). The Gojali example makes clear that the migration and development interactions go much beyond remittance backflows and migrants returning to the sending region. Remittances have become as much translocalised as the underlying social structures of the households, family networks and communities. Non-returning migrants are not lost for the community of the sending region but remain firmly embedded in translocal social structures stretching to their place of origin. In the case of Gojal, remittances are increasingly flowing between third places within translocal social networks, often without touching the ground in the sending region. These "network remittances" call into question established bi-polar concepts of remittances as unidirectional transfers originating from the migration destination and exclusively addressed to the sending region, which still prevail in the migration and development debates (Cohen, 2011; de Haas, 2007b; Raghuram, 2009). Even more, the Gojali example points to a blind spot of these debates in the midst of a persisting "remittance boom" (de Haas, 2010:230). By overly narrowing down the scholarly focus on remittance flows and their impacts, the importance of enhanced opportunity structures emerging in the context of migration, has been widely neglected. The Gojali example illustrates well how every single new migrant not only meant an additional anchor point in expanding translocal networks, but also potentially functioned as on-site supporter and facilitator for subsequent migrants, thus broadening their viable livelihood options. Prevailing bi-polar concepts of remittances are rooted in the idea of a territorialised development focussing on change in a certain, delimitable sending region. The underlying assumptions of a sedentary norm and the congruence between social and geographical spaces become more and more obsolete in contexts of ongoing migration. Social spaces increasingly cut across territorial boundaries. Ongoing mobility and circulation thwart any attempts to unequivocally allocate people to a certain territory. The production of social space has disentangled from closed territorial notions. Development, understood as a people-centred concept aiming at enhancing capabilities and expanding freedoms of human beings (Sen, 1999), needs to address these new socio-spatial configurations. The example of Gojal underlines that development has to be understood as a translocal phenomenon, disentangled from and cutting across territories but nevertheless multilocally anchored in space.

Acknowledgements. The research for this study was kindly sponsored by the German Federal Ministry of Education and Research (BMBF) in the context of the competence network "Crossroads Asia. Conflict, Migration, Development" (reference number: 01UC1103E), conducted in the sub-project "Networks of Knowledge" at the Centre for Development Studies (ZELF), Freie Universität Berlin, Germany.

Edited by: B. Korf

Reviewed by: two anonymous referees

\section{References}

AKRSP (Aga Khan Rural Support Programme): An Assessment of Socio-Economic Trends in the Northern Areas and Chitral, Pakistan (1991-2005), AKRSP, Gilgit, 2007.

Bähr, J., Jentsch, C., and Kuls, W.: Bevölkerungsgeographie, de Gruyter, Berlin, New York, 1992.

Bebbington, A. J. and Batterbury, S. P. J.: Transnational Livelihoods and Landscapes: Political Ecologies of Globalization, Cultural Geographies, 8, 369-380, 2001.

Benz, A.: Education for Development in Northern Pakistan. Opportunities and Constraints of Schooling for the Improvement of Rural Households' Living Conditions, Ph.D. thesis, Freie Universität Berlin, Berlin, 2012.

Benz, A.: How migrants made their way: The role of pioneering migrants and solidarity networks of the Wakhi of Gojal (Northern Pakistan) in shaping the dynamics of rural-urban migration, Crossroads Asia Working Paper Series, 11, Crossroads Asia, Bonn, 2013a.

Benz, A.: Education and Development in the Karakorum: Educational Expansion and its Impacts in Gilgit-Baltistan, Pakistan, Erdkunde, 67, 123-136, 2013b.

Bose, A.: Demography of Himalayan Villages: Missing Men and Lonely Women, Econ. Polit. Weekly, 35, 2361-2363, 2000.

Carney, D. (Ed.): Sustainable Rural Livelihoods. What contribution can we make?, Department for International Development, London, 1998.

Chambers, R.: Sustainable livelihoods, environment and development: putting poor rural people first, IDS Discussion Paper, 240, Institute of Development Studies, University of Sussex, Brighton, 1987.

Chambers, R. and Conway, G. R.: Sustainable Rural Livelihoods: Practical Concepts for the 21st Century, IDS Discussion Paper, 296, Institute of Development Studies, University of Sussex, Brighton, 1992.

Cohen, J. H.: Migration, Remittances and Household Strategies, Ann. Rev. Anthropol., 40, 103-114, 2011.

de Haan, L.: Livelihoods and Globalisation, paper presented at the International Conference on Research for Development, Bern, 24 July 2008.

de Haan, L.: The Livelihood Approach: A Critical Exploration, Erdkunde, 66, 345-357, 2012. 
de Haan, L. and Zoomers, A.: Development Geography at the Crossroads of Livelihood and Globalisation, Tijdschrift voor Economische en Sociale Geografie 94, 350-362, 2003.

de Haas, H.: Migration and Development: A Theoretical Perspective, COMCAD Working Papers, 29, Center on Migration, Citizenship and Development, Bielefeld, 2007a.

de Haas, H.: Remittances, Migration and Social Development. A Conceptual Review of the Literature, Social Policy and Development Programme Paper, 34, United Nations Research Institute for Social Development (UNRISD), New York, 2007b.

de Haas, H.: Migration and Development: A Theoretical Perspective, Int. Migr. Rev., 44, 227-264, 2010.

de Haas, H.: The Migration and Development Pendulum: A Critical View on Research and Policy, Int. Migr., 50, 8-25, 2012.

DFID (Department for International Development): Sustainable Livelihoods Guidance Sheets, Department for International Development, London, 1999.

Ellis, F.: Household strategies and rural livelihood diversification, J. Dev. Stud., 35, 1-38, 1998.

Ellis, F.: Rural livelihoods and diversity in developing countries, Oxford University Press, Oxford, 2000.

Elmhirst, R.: Displacement, Resettlement, and Multi-Local Livelihoods, Critical Asian Studies, 44, 131-152, 2012.

Faist, T.: The Volume and Dynamics of International Migration and Transnational Social Spaces, Clarendon Press, Oxford, 2000.

Farrington, J., Ramasut, T., and Walker, J.: Sustainable Livelihoods Approaches in Urban Areas: General Lessons, with Illustrations from Indian Cases, ODI Working Paper, 162, Overseas Development Institute, London, 2002.

Geiger, M. and Steinbrink, M.: Migration und Entwicklung: Merging Fields in Geography, in: Migration und Entwicklung. Beiträge aus geographischer Perspektive, edited by: Geiger, M. and Steinbrink, M., IMIS-Beiträge, 42, Institut für Migrationsforschung und Interkulturelle Studien, Osnabrück, 7-35, 2012.

Greiner, C.: Patterns of Translocality: Migration, Livelihoods and Identities in Northwest Namibia, Sociologus, 60, 131-161, 2010.

Greiner, C.: Can Households be Multilocal? Conceptual and Methodological Considerations based on a Namibian Case Study, Die Erde, 143, 195-212, 2012.

Hegland, M. E.: Tajik Male Labour Migration and Women Left Behind: Can They Resist Gender and Generational Hierarchies?, Anthropology of the Middle East, 5, 16-35, 2010.

Hoermann, B. and Kollmair, M.: Labour Migration and Remittances in the Hindu Kush-Himalayan Region, International Centre for Integrated Mountain Development (ICIMOD), Kathmandu, 2009.

King, B.: Spatialising livelihoods: resource access and livelihood spaces in South Africa, T. I. Brit. Geogr., 36, 297-313, 2011.

Kreutzmann, H.: Hunza: Ländliche Entwicklung im Karakorum, Reimer, Berlin, 1989.

Kreutzmann, H.: Ethnizität im Entwicklungsprozess. Die Wakhi in Hochasien, Reimer, Berlin, 1996.

Lohnert, B. and Steinbrink, M.: Rural and Urban Livelihoods. A translocal perspective in a South African context, South African Geographical Journal, 87, 95-103, 2005.

Long, N.: Translocal Livelihoods, Networks of Family and Community, and Remittances in Central Peru, in: Migration and Development within and Across Borders: Research and Policy Perspectives on Internal and International Migration, edited by:
DeWind, J. and Holdaway, J., International Organization for Migration, Geneva, New York, 39-70, 2008.

Malik, A. and Piracha, M.: Economic Transition in Hunza and Nagar Valleys, in: Karakoram in Transition. Culture, Development, and Ecology in the Hunza Valley, edited by: Kreutzmann, H., Oxford University Press, Karachi, 359-369, 2006.

Marcus, G. E.: Ethnography in/of the World System: The Emergence of Multi-Sited Ethnography, Ann. Rev. Anthropol., 24, 95 117, 1995.

Massey, D.: A global sense of place, Marxism Today, June 1991, 24-29, 1991.

Mazibuko, S.: Understanding underdevelopment through the sustainable livelihoods approach, Community Development, 44, 173-187, 2012.

Müller-Mahn, D. and Verne, J.: Geographische Entwicklungsforschung. Alte Probleme, neue Perspektive, Geographische Rundschau, 62, 4-11, 2010.

Nazar, A.: Evolution of Education in Hunza, the Northern Areas of Pakistan. Views of Early Teachers of Hunza, Master thesis, Institute of Educational Development, Aga Khan University [unpublished], Karachi, 2009.

Olimova, S. and Olimov, M.: Labor Migration from Mountainous Areas in the Central Asian Region: Good or Evil?, Mountain Res. Dev., 27, 104-108, 2007.

Raghuram, P.: Which migration, what development? Unsettling the edifice of migration and development, Population, Space and Place, 15, 103-117, 2009.

Rakodi, C.: The household strategies of the urban poor. Coping with poverty and recession in Gweru, Zimbabwe, Habitat International, 19, 447-471, 1995.

Rakodi, C. (Ed.): Urban Livelihoods: A People-centred Approach to Reducing Poverty, Earthscan, London, 2002.

Sati, V. P. and Singh, R. B.: Migration and Agrarian Changes in Mountain Regions. A Case Study of the Pindar Basin of Uttarakhand Himalaya, Annals of NAGI, 29, 20-33, 2009.

Scoones, I.: Sustainable Rural Livelihoods. A Framework for Analysis, IDS Working Paper, 72, Institute of Development Studies, University of Sussex, Brighton, 1998.

Scoones, I.: Livelihoods perspectives and rural development, The Journal of Peasant Studies, 36, 171-196, 2009.

Sen, A.: Development as freedom, Oxford University Press, Oxford, 1999.

Skeldon, R.: Migration and development. Over twenty years of research: progress and prospects, in: Migration in a Globalised World. New Research Issues and Prospects, edited by: Audebert, C. and Dorai, M. K., Amsterdam University Press, Amsterdam, 145-160, 2010.

Sökefeld, M.: Migration and Society in Gilgit, Northern Areas of Pakistan, Anthropos, 92, 83-90, 1997.

Sökefeld, M.: The Attabad Landslide and the Politics of Disaster in Gojal, Gilgit-Baltistan, in: Negotiating disasters: politics, representation, meanings, edited by: Luig, U., Lang, Frankfurt a.M., 175-204, 2012.

Steinbrink, M.: Exploring the Role of Migrants' Networks in the Context of Translocal Livelihoods in South Africa, in: Social Networks. Potentials and Constraints. Indications from South Africa, edited by: Lohnert, B., Verlag für Entwicklungspolitik, Saarbrücken, 73-114, 2007. 
Steinbrink, M.: Leben zwischen Land und Stadt: Migration, Translokalität und Verwundbarkeit in Südafrika, Verlag für Sozialwissenschaft, Wiesbaden, 2009.

Steinbrink, M.: Migration, Netzwerk und >Entwicklung<. Translokale Livelihoods in Südafrika, in: Migration und Entwicklung. Geographische Perspektiven, edited by: Geiger, M., and Steinbrink, M., IMIS-Beiträge, 42, Institut für Migrationsforschung und Interkulturelle Studien, Osnabrück, 165-203, 2012.

Steinbrink, M. and Lohnert, B.: Jenseits von Land und Stadt. Plädoyer für eine translokale Perspektive in der Migrations- und Verwundbarkeitsforschung im globalen Süden, in: Migrationsund Integrationsforschung. 20 Jahre IMIS, edited by: Oltmer, J. and Pott, A., IMIS-Schriften, 16, Institut für Migrationsforschung und Interkulturelle Studien, Göttingen, 2012.
Thieme, S.: Sustaining Livelihoods in Multi-local Settings: Possible Theoretical Linkages Between Transnational Migration and Livelihood Studies, Mobilities, 3, 51-71, 2008.

van Dijk, T.: Livelihoods, capitals and livelihood trajectories, Prog. Dev. Stud., 11, 101-117, 2011.

Zoomers, A. and van Westen, G.: Introduction: translocal development, development corridors and development chains, International Development Planning Review, 33, 377-388, 2011. 